\title{
Assessment of Nutritional Status in Dairy Cows Using Biological Indicators
}

\author{
V.Meenalochani*, C.Chandrasekaran, M.Murugan, M.Purusothaman, \\ P.Vasanthakumar
}

\begin{abstract}
The present investigation was conducted to assess biological indicators reliable for assessing the nutritional status of dairy cows under field conditions. The serum biological indicators for assessment of energy includes glucose, cholesterol and NEFA in Jx in this study varied from 42.73 to $46.78 \mathrm{mg} / \mathrm{dl}, 142$ to $177 \mathrm{mg} / \mathrm{dl}$ and 0.56 to $0.61 \mathrm{mmol} / \mathrm{l}$ respectively at different physiological stages. In HFx serum biological indicators for assessment of energy includes glucose, cholesterol and NEFA varied from 37.76 to $52.17 \mathrm{mg} / \mathrm{dl}$, 96 to $109 \mathrm{mg} / \mathrm{dl}$ and 0.41 to 0.72 , mmol/l respectively at different physiological stages and were within the reference range value. As the deficit percent of TDN in both breeds varied from 6.8 to 14.6 per cent, it was not well expressed in serum NEFA level but in HFx during late lactation it was more than $0.7 \mathrm{mmol} / \mathrm{l}$. indicating as critical alarm for the occurrence of metabolic diseases at later stages. The serum biological indicators for assessment of protein status includes total protein, albumin, globulin, BUN and MUN in Jx varied from 8.80 to $9.61 \mathrm{~g} / \mathrm{dl}$ and 3.15 to $3.48 \mathrm{~g} / \mathrm{dl}$ and 5.64 to $6.13 \mathrm{~g} / \mathrm{dl}$ and 15.47 to $16.37 \mathrm{mg} / \mathrm{dl}$ and 8.9 to $8.81 \mathrm{mg} / \mathrm{dl}$, respectively and was comparable during different physiological stages. In HFx total protein, albumin, globulin, BUN and MUN varied from 7.88 to $8.89 \mathrm{~g} / \mathrm{dl}$ and 3.04 to $3.73 \mathrm{~g} / \mathrm{dl}$ and 4.84 to $5.31 \mathrm{~g} / \mathrm{dl}$ and 15.26 to $16.66 \mathrm{mg} / \mathrm{dl}$ and 8.51 to $9.58, \mathrm{mg} / \mathrm{dl}$ respectively at different physiological stages. As the deficit percent of intake CP in both breeds varied from 19 to 34.7 it was well indicated by the concentration of milk urea nitrogen ( 8.51 to $9.58 \mathrm{mg} / \mathrm{dl}$ ) as the MUN value below 11 per cent was indicative of protein deficiency. The biological indicator for assessment of mineral status by calcium in Jx varied from 7.26 to $7.56 \mathrm{mg} / \mathrm{dl}$ and in HFx 8.48 to $9.44 \mathrm{mg} / \mathrm{dl}$ at different physiological stages. Though the deficiency of calcium intake varied from 8.2 to 28.8 percent in Jx and 8.2 to 23.4 in HFx at different physiological stages it was not identified in the serum due to the existence of homeostasis mechanism. The excess phosphorus intake was not identified by serum level though it varied from 4.25 to $5.71 \mathrm{mg} / \mathrm{dl}$ and varied from 5.7 to $6.54 \mathrm{mg} / \mathrm{dl}$ in HFx at various physiological stages as the excess intake being excreted through faeces and urine. Hence mineral deficit cannot be identified by serum biological indicators.
\end{abstract}

Keywords: Dairy cows - Nutritional status - biological indicators

\section{Introduction}

Majority of dairy cows are reared under grazing system with limited supplementation of green fodder, dry fodder and concentrate feed. But optimum productive and reproductive efficiency of livestock could be achieved only if the animals fed with the required quantity of feedstuffs and all nutrients in proper proportion(NRC, 2001).The actual intake of the animal for it's production capability cannot be ascertained and hence the energy and protein status of the animals under field conditions are very difficult to assess.

In the dairy Industry, the use of metabolic profiles for assess in the nutritional and health status of cows is wide spread (Grunwaldt et al.,2000). The blood metabolites give an immediate indication of an animal's nutritional status at the point of time ( Pambu- Gollah et al.,2000) is becoming popular. (Ndlovu et al., 2007). Serum concentrations of metabolites such as glucose, cholesterol, non esterified fatty acids(NEFA), Total protein, albumin, globulin, blood urea nitrogen (BUN), milk urea nitrogen(MUN), and minerals are commonly used to assess the nutritional status of dairy cows. Thus the present investigation was done to assess the nutritional status of Jersey cross \& Holstein Friesian cross dairy cows using blood metabolites under field conditions of Dharmapuri district.

\section{Materials And Methods}

The study was conducted in Dharmapuri district with $101 \mathrm{Jx}$ and $112 \mathrm{HFx}$ cows . The data regarding nutritional status of animals were collected from the selected farmers through face to face interview with the help of well structured questionnaire. It includes recording of body measurements, feeding pattern, quantity of feed and fodder offered during 24 hours, milk yield, Besides, this the amount nutrients intake from fodders were calculated by considering average nutritive values of the respective fodders.(Ranjhan 1998). The mean nutrient deficit in terms 
of Dry matter(DM), total digestible nutrient(TDN),crude protein(CP) calcium $(\mathrm{Ca})$ and phosphorous $(\mathrm{P})$ intake at various physiological stages for both the breeds was calculated as per NRC (2001) feeding standard were and were furnished in table 1 and 2 .

A total 213 lactating dairy cows of Jx and HFx were used for the analysis of blood metabolites.Ten $\mathrm{ml}$ of blood was collected from the jugular vein of each animal and serum was separated for analysis of glucose, cholesterol, and non esterified fatty acids, to assess the energy status and total protein, albumin, globulin, blood urea nitrogen were estimated for assessing the protein status, calcium and phosphorous were measured for assessment of mineral status with commercial kits and as per manufacturers protocol. The data obtained were subjected to statistical analysis as per Snedecor and Cochran (1994) and the data was subjected to analysis of variance (ANOVA) and t-test. Further, means were compared using Duncan's multiple range test by using the soft ware package SPSS version 12 (SPSS, 1996).

\section{Results}

The per cent dry matter deficit in $\mathrm{Jx}$ was $13.8,4.7,16.9$ in early, mid, late lactation respectively and significantly higher (+1.6) during late gestation. In HF x dry matter deficit per cent was 10.9, 2.5, 11.0 and 10.3 during early, mid and late lactation and late gestation , respectively. The deficit per cent of TDN in Jx was 14.6,7.6 10.6 and 13.4 in early, mid and late lactation and late gestation, respectively. In HFx the deficit per cent of TDN during early, mid and late lactation and late gestation was 12.3, 6.8, 9.8 and 7.7 in HFx and was significantly higher in early lactation in both breeds. (table 1and 2)

Hence,the study revealed that the percent of deficit was noticed in DMI, TDN, CP and calcium intake and excess was found in phosphorus intake. Among the nutrients intake, deficit of crude protein was significantly high and deficit per cent was felt during early lactation on both breeds comparing with the different physiological stages.

The serum biological indicators for assessment of energy status includes Glucose, Cholesterol,and Non esterified fatty acid. These values for the dairy cows in early, mid and late lactation, late gestation were furnished in table 3 .The mean glucose value for early, mid and late lactation, late gestation (table -3) were within the reference range values. (table-4). But the glucose concentration in $\mathrm{Jx}$ was significantly less and was comparable in other physiological stages. But,in HFx it was significantly less during early lactation and significantly high during late gestation, even though the TDN deficit was noticed in all physiological stages.

There was no significant difference in serum cholesterol level between physiological stages, even though the per cent of TDN deficit was noticed in both breeds. But the cholesterol concentration in Jx was less in late lactation and highest in early lactation, whereas in HFx, the concentration was less in late gestation and highest in mid lactation. The serum NEFA concentration was comparable in JX during various physiological stages and agreed with the reference value in Table 4. In HFx it was significantly higher during late lactation suggesting, restricted feeding practice was adopted by the farmers as the milk yield decreased during late lactation. Further, Ospina et al. (2010) stated that NEFA levels more than $0.7 \mathrm{mmol} / \mathrm{l}$ was defined as critical alarm as it leads to occurrence of various metabolic diseases in later stages.

Further, the per cent deficit of CP was 34.7, 24.4, 31.2 and 30.6 in Jx and 30.0, 19, 31.4 and 22 in HFx during early, mid and late lactation and late gestation, respectively. The deficit per cent was significantly less during mid lactation in both breeds. The serum total protein value for late gestation, early, mid, and late lactation, were $9.61,8.80,9.31$ and $8.94 \mathrm{~g} / \mathrm{dl}$ in $\mathrm{Jx}$ and $8.89,8.31,8.50$ and $7.88 \mathrm{~g} / \mathrm{dl}$, respectively and is given in Table 1.The serum total protein, albumin, globulin, blood urea nitrogen, milk urea nitrogen value for late gestation, early, mid, and late lactation, were furnished given in table 3 . Theserum taoatl protein values were slightly higher than the reference range values of table 4 , though the animals consumed diet deficient in protein. In HFx cows, the concentration was significantly less in late lactation and significantly higher in late gestation. The concentration was comparable in Jx and significantly lower in late gestation in HFx.

The serum albumin values in $\mathrm{Jx}$ and HFx during late gestation, early, mid and late lactation, were furnished in table 3 and was within the reference range values $(1.6-5.5 \mathrm{~g} / \mathrm{dl})$ in table 4 . Further, it was comparable in the physiological stages in Jx, whereas in HFx significantly it higher in late gestation and was comparable at various lactation stages.The serum globulin values in various physiological stages were furnished in table 1 and agreed with the reference range value. table 4.

The serum BUN value were in table 3 and was within the reference value given $(2-34 \mathrm{~g} / \mathrm{dl})$ and the variation was comparable in Jx and in HFx there was significant difference between various lactation stages. The MUN values in milk for Jx and HFx, are presented in table 3 and were within the reference value (7.0- $17.6 \mathrm{mg} / \mathrm{dl}$ ) as per the Table 4 . The serum calcium ( 6.5 to $12.4 \mathrm{mg} / \mathrm{dl})$ and phosphorus values ( 2.6 to $8.6 \mathrm{mg} / \mathrm{dl})$. were within the 
reference values and presented in the table 3 . Further,the deficit per cent of calcium was significantly higher in early lactation in both breeds.

\section{Discussion}

The serum glucose concentration in both breeds agreed with the reports of Herdt (2000) stated blood glucose was under hormonal control, hence the level of glucose was insensitive index of energy intake. The result was in contrary with the findings of Farver (1997) as he stated there was no significant difference in glucose values as noticed between stages of lactation and Sivaraman (1998), stated that glucose level was highest during late lactation and less during mid lactation.

But the cholesterol concentration in this report was in contrary with the values of Rowlands et al. (1980) who reported that there exist significant difference in cholesterol concentration between physiological stages. Ospina et al. (2010) stated that NEFA levels more than $0.7 \mathrm{mmol} / \mathrm{l}$ was defined as critical alarm as it leads to occurrence of various metabolic diseases in later stages. Hence, NEFA acted as a good biological indicator for energy deficit diet in field conditions and corroborated with the report of Radostitis et al. (1994) that in marginal energy imbalance, blood glucose and cholesterol were unreliable indices of adequacy of energy, due to its excessive variability, but non esterified fatty acids was a sensitive indicator for assessment of energy status in dairy cows.

The serum total protein was comparable in $\mathrm{Jx}$ between physiological stages, , and was similar with the report of, Filipejova and Kovacik. (2009) and Mohebbi Fani et al. (2005) who observed there was no significant difference between lactation and gestation. Though the CP deficit per cent ranged between 24.4 and 34.7 in the study area it did not influence the serum total protein value. The globulin value varied among themselves it was comparable in both breeds. The results agreed with the findings of Sivaraman. (1998)and Hayashi et al. (2005), who stated in globulin level there existed no significant difference in various physiological stages. The BUN value in both breeds was less during late lactation showed the reduction in milk yield during late lactation forced the farmers to adopt restricted feeding. This study was similar with the findings of Sivaraman. (1998) as he stated there existed no significant difference on BUN concentration at various physiological stages.

The MUN value in Jx was comparable between physiological stages, and in HFx it was significantly higher in mid lactation. This result agreed with the findings of Hoff et al. (1997) and Hwang et al. (2000), reported that MUN value less than $11 \mathrm{mg} / \mathrm{dl}$ was suggestive of protein deficiency, as the per cent of protein deficiency was more in the study area, the result obtained is justified. Further, the research report agreed with Wambugu et al. (1996) as MUN value of $8.7 \mathrm{mg} / \mathrm{dl}$ was noticed in protein deficit diet fed animals and $17.6 \mathrm{mg} / \mathrm{dl}$ in the adequately protein fed animals when compared to control group. As the MUN value ranged between 8.51 and 9.58 , as agreed with protein deficiency in the study area (19 to 34.7 per cent) and it was concluded that MUN acts as a good biological indicator of protein deficiency.

In $\mathrm{Jx}_{\mathrm{X}}$, the serum calcium level was comparable at various physiological stages and in HFx it was significantly higher in mid lactation. The reason may be due to the increased milk yield in mid lactation in HFx when compared to other lactation stages prompting increased osteoclastic activity. This report was in agreement with that of Sivaraman. (1998) as he stated that though the concentration of calcium varied among themselves, it was not significant. Further, calcium level was very low in early lactation for both the breeds as most of the farmers were unaware of feeding needed calcium to the cows during lactation. The concentration of phosphorus was significantly high in late gestation and it was comparable between various stages of lactation in Jx. In HFx though the values varied among themselves during various physiological stages, they were non significant.

\section{Conclusion}

The biological indicators were not significantly reliable for assessing the nutritional status of dairy cows in field conditions except for NEFA for assessment of energy status and MUN for assessment of protein status. Hence the report agrees with the findings of Maurya and Singh (2015) and Madziga et al.,(2013) stating that physiological status and breed have no significant impact on biological indicators and hence the biochemical profiles must be combined with traditional methods for assessment of nutritional status

\section{Acknowledgement}

The authors are grateful to the Tamil Nadu Veterinary and Animal Sciences University for providing necessary financial assistance for carrying out the research work

\section{References}

[1]. Alacam, E., D. Tuncer, R. Salmanoglu, M. S. Kucukersan, M. Kucukersan and Abdurrahman ozluer, 2008. The effect of a nutritionally unbalanced diet on some blood and post partum fertility in dairy cows.Turk. J. Vet. Anim.Sci., 32: 99-106. 
[2]. Anderson,D.E and M. Rings (2009) Current Veterinary Therapy: Food Animal practice. St.Louis,MO :Saun Elsevier.

[3]. Arunaman, S., 2002. Metabolic profile test during perparturient diseases. M.V.Sc., thesis submitted to TANUVAS , Chennai.

[4]. Baker, L. D., J. D. Ferguson and W.Chalupa,.1995. Responses in urea and true protein on milk to different protein feeding schemes for diary cows. J.Dairy Sci., 78: 2424-2434.

[5]. Bakshi, M. P. S. and M. Wadhwa, 2011. Nutritional status of dairy animals in different regions of Punjab state in India. J.Anim. Sci. 81 : $52-58$.

[6]. Farver, T.B., 1997. Concepts of normality in clinical biochemistry.II. Reference interval determination and use.In: Kanekoj., Harvey ,J., Bruss,m, (Eds),Clinical Biochemistry of domestic animals , 5 ed - Academic Press , San Diego, pp 2-9.

[7]. Ferguson,J.D., and Chalupa, W. 1989. Impact of protein nutrition on reproduction in dairy cows. Journal of Dairy Science, 72:746-66

[8]. Filipejova J. Kovacik, 2009. Evaluation of selected biochemical parameters in blood plasma ,urine and milk of dairy cows during the lactation period. Stovak .J. Anim.Sci., 42: 8-12.

[9]. Grunwaldt, E. G., J. C. Guevara, O. R. Estevez, A. Vicente, Rousselle, H. N. Alcunten, D. Aguerregaray and C. R. Stasi, 2005. Biochemical and Hematological measurements in beef cattle in Mendoza plain range lands(Agerntina).Trop.Anim.Hlth.Prod., 37(6): 527-540.

[10]. Hayashi, Y., S. Shah, S. K. Shah and H. Kumagai , 2005. Dairy production and nutritional status of lactating buffalo and cattle in small -scale farms in Terai, Nepal. Livestock research for rural development . 17: 132-141.

[11]. Herdt, T.H., 2000.Variability Characteristics and test selection in herd- level nutritional and metabolic profile testing. Veterinary Clinics of North Amercia :Food Anim.Prac.,16:387-403.

[12]. Hoff, G., M.D. Vervoorn, J.P. Lenaes and Tammings, 1997. Milk urea nitrogen as a tool to monitor the protein nutrition of dairy cows.J. Dairy Sci., 80: 3333-3340.

[13]. Hwang Sen-yuan, Mei-juLee and Peter wen-shyg Chiou, 2000. Monitoring Nutritional status of dairy cows in Taiwan using milk protein and milk urea nitrogen. Asian - Aus. J. Anim. Sci., 13:1667-1673.

[14]. Jerry Kaneko, J. J., J. W. Harvey and M. L. Bruss, 1997. Clinical Biochemistry of Domestic Animals.5 ${ }^{\text {th }}$ edition. Acaemic Press,New York.

[15]. Kida, K. 2002. The metabolic profile test: its practicability in assessing feeding management and peripaturient diseases in high yielding dairy herds .J. Vet.Med.Sci., 64: 557-563.

[16]. Lazarus, A.E. and M. Thiagrajan, 1980. Preliminary report on metabolic profile testing in a dairy herd.Livestock adviser., 62: 11-15.

[17]. Msdziga,C.B.I.,O.S.Alawa., O.S.Lamidi and D.Y.Goska,2013.Assessing the nutritional ststaus of four indigenous breeds of cattle using some blood metabolites of Nigeria.J.of Biology, Agriculture and Health care.,3:3334-3208

[18]. Maurya,S.k.and O.P. Singh. 2015. Assessment of blood biochemical profile and nutritional status of buffaloes under field conditions. Buffalo Bulletin., 34: 161-167

[19]. Merck Veterinary Manual. 2011. Metabolic disorders.Hepatic lipidosis.Fatty liver disease of Cattle. http: // www. Merck vetmanual. $\mathrm{com} / \mathrm{mvm} /$ index.jsp?cile+htm/bc/80801 htm\&word= cholesterol.

[20]. Mohebbi-Fani.,S.S.Shekarforoush, N.Ahid and M.Dehdari, 2005. Changes in and correlations between some serum constituents and milk components from early to late lactation in a dairy herd with sub clinical production disorders., Iranian Journal of Veterinary Research, University of Shiraz, Vol 6:(2) 1111-1120.

[21]. Ndlovu.T., M. Chimonyo, A. I. Okoh, V. Muchenje, K. Dzama, S. Dube and J.G. Raats, 2007. Assessing the nutritional status of beef cattle; current practices and future prospects. African journal of biotechnology. 6: 2727-2734.

[22]. NRC. 2001. Nutrient requirements of dairy cattle. $7^{\text {th }}$ revised ed.,.National Research Council. National Academy Press., Washington, DC.

[23]. Ospina, P. A., D. V. Nydam, T. Stokol and T. R. Overton, 2010. Evaluation of nonesterified fatty acids and $\beta$-hydroxybutyrate in transition dairy cattle in the northeastern United States: Critical thresholds for prediction of clinical diseases. J. Dairy Sci., 93: $546-554$.

[24]. Pambu-Gollah, R.P., P. B. Cronje, N.H. Casey, 2000. An evaluation of the use of blood metabolite concentrations as indicators of nutritional status in free ranging goats. S. Afr. J. Anim. Sci., 30: 115-120.

[25]. Radostitis, O. M., Blood, D. C and Gay, C. C. 1994. In Veterinary Medicine, .A text book of the diseases of Cattle,Sheep,Pigs, Goats and Horses $8^{\text {th }}$ edition. The English language book society, Bailliere Tindali, London.

[26]. Ramakrishna, K. V. 2003. Studies on blood chemical constituents of cross bred Jersey cross maintained under varied nutritional managements. Indian Veterinary Journal. 80: 698-699.

[27]. Ranjhan, S.K. 1998. Nutrient requirements of livestock and poultry.Second Revised edn. Indian Council of Agricultural Research. Krishi Anusandhan Bhavan, Pusa, New Delhi.

[28]. Rowland, G.J, R. Manstona, A. J. Starka1, A. M. Russella, K. A. Collisa1 and S. C. Collisa.(1980): Changes in albumin, globulin, glucose and cholesterol concentration in a blood of dairy cows in a late pregnancy and early lactation. J. of Agri. Sci. (Cambridge) 94: 517-527.

[29]. Sivaraman,T., 1998. Application of metabolic profile test in dairy herd health management. Ph.D., Thesis submitted to TANUVAS, Chennai.

[30]. Somer, H. 1991. Blood and milk profiling in dairy cattle for health and nutrition control. Symposium of health and productive control systems in animal herds.Pig research Institute.Taiwan.Chaunan,Taiwan .pp. 28-29.

[31]. Snedecor, G.W. and W.G. Cochran, 1994 .Statistical methods .Oxford and I.B.H. publications, New Delhi, India.

[32]. SPSS. 1996. Statistical packages for Social Sciences. Ver.12, SPSS Inc.,Linois, USA.

[33]. Wadhawa, M., S. Kaushal, M.P.S. Bakshi and O.S. Parmar, 2005. Assessment of nutritional status of lactating cross bred cows. Indian J. Anim. Nutr., 22: 144-151.

[34]. Wambugu, M., R.G. Wahome, C. Gachuiri, J. Tanner and R.Kaitho, 1996. Evaluation of the use of milk urea nitrogen (MUN) as an indicator of nutritional status of dairy cattle in small holder farms in Kaimbu district. . J. Dairy Sci., 79: 2424-2434.

[35]. William O. Reece., 2005. Dukes Physiology of Domestic Animals. $12^{\text {th }}$ rev.ed.Panima Publishing Corporation, New Delhi / Bangalore.

[36]. Zinpro Performance Panel,2011.'Ask Zinpro" computer program. Oregon State University. 2012.College of Veterinary medicine.Veterinary Diagnostic Laboratory.Reference ranges. http:// oregonstate. edu/vetmed /sites/ default /files/ CPBiochemistry Reference.Ranges 04- 09 . 
Table -1: Percentage deficit /excess of nutrient intake of $\mathrm{Jx}$ cows at different physiological stages in relation to NRC (2001) feeding standards.

\begin{tabular}{|c|c|c|c|c|}
\hline Parameters & $\begin{array}{c}\text { Early lactation } \\
(\mathbf{n}=\mathbf{3 0})\end{array}$ & $\begin{array}{c}\begin{array}{c}\text { Mid lactation } \\
(n=30)\end{array} \\
\end{array}$ & $\begin{array}{c}\text { Late Lactation } \\
(\mathbf{n}=\mathbf{2 3})\end{array}$ & $\begin{array}{c}\text { Late gestation } \\
(n=18)\end{array}$ \\
\hline Body weight ( $\mathrm{kg}$ ) & $333 \pm 4$ & $347 \pm 11$ & $337 \pm 4$ & $377^{\mathrm{a}} \pm 12$ \\
\hline \multicolumn{5}{|l|}{ Dry matter (DM) } \\
\hline $\begin{array}{l}\text { Requirement } \\
\text { (kg/day ) }\end{array}$ & $9.23 \pm 0.06$ & $11.17 \pm 0.27$ & $9.56 \pm 0.10$ & $8.26 \pm 0.28$ \\
\hline Intake (kg/day) & $7.95 \pm 0.11$ & $10.69 \pm 0.34$ & $7.93 \pm 0.17$ & $8.38 \pm 0.31$ \\
\hline Shortage( $\mathrm{kg} /$ day $)$ & $1.28 \pm 0.11$ & $0.48 \pm 0.14$ & $1.63 \pm 0.17$ & $0.12 \pm 0.14$ \\
\hline Shortage $(\%)$ & $13.8^{\mathrm{a}} \pm 1.22$ & $4.7^{\mathrm{b}} \pm 1.46$ & $16.9^{\mathrm{a}} \pm 1.84$ & $\begin{array}{c}\mathrm{c} \\
+1.6^{\mathrm{c}} \pm 2.81\end{array}$ \\
\hline \multicolumn{5}{|l|}{ Total digestible nutrient (TDN) } \\
\hline Recommended (g/day) & $6127.74 \pm 34.73$ & $6613.35 \pm 184.45$ & $5125.07 \pm 68.97$ & $5068.12 \pm 97.76$ \\
\hline Intake (g/day) & $5229.45 \pm 63.65$ & $6113.35 \pm 202.67$ & $4580.49 \pm 53.88$ & $4387.52 \pm 158.43$ \\
\hline Shortage (g/day) & $898.29 \pm 59.51$ & $475 \pm 0.60 .72$ & $554.58 \pm 64.84$ & $675.60 \pm 126.21$ \\
\hline Shortage $(\%)$ & $14.6^{\mathrm{a}} \pm 0.97$ & $7.6^{\mathrm{b}} \pm 1.11$ & $10.6^{\mathrm{ab}} \pm 1.16$ & $13.4^{\mathrm{a}} \pm 2.59$ \\
\hline \multicolumn{5}{|l|}{ Crude protein $(\mathrm{CP})$} \\
\hline Recommended (g/day) & $1210.05 \pm 4.72$ & $1304.06 \pm 41.74$ & $935.99 \pm 15.76$ & $909.49 \pm 13.06$ \\
\hline Intake (g/day) & $792.72 \pm 11.07$ & $992.36 \pm 54.22$ & $641.99 \pm 10.77$ & $632.39 \pm 29.18$ \\
\hline Shortage (g/day) & $417.33 \pm 9.7$ & $311.70 \pm 41.08$ & $293.99 \pm 13.54$ & $277.10 \pm 25.70$ \\
\hline Shortage $(\%)$ & $34.7^{\mathrm{a}} \pm 0.87$ & $24.4^{\mathrm{b}} \pm 3.20$ & $31.2^{\mathrm{ab}} \pm 1.11$ & $30.6^{\mathrm{ab}} \pm 2.94$ \\
\hline \multicolumn{5}{|l|}{ Calcium (Ca) } \\
\hline $\begin{array}{l}\text { Recommended } \\
\text { (g/day) }\end{array}$ & $48.75 \pm 0.27$ & $52.82 \pm 1.54$ & $38.6 \pm 0.58$ & $38.76 \pm 0.86$ \\
\hline Intake ( g/day) & $34.71 \pm 0.75$ & $46.92 \pm 1.86$ & $35.43 \pm 0.70$ & $29.39 \pm 0.55$ \\
\hline Shortage ( g/day) & $14.03 \pm 0.73$ & $5.9 \pm 1.68$ & $3.17 \pm 0.87$ & $9.37 \pm 0.87$ \\
\hline Shortage $(\%)$ & $28.8^{\mathrm{a}} \pm 1.50$ & $11.2^{\mathrm{b}} \pm 2.86$ & $8.2^{b} \pm 2.24$ & $24.2^{\mathrm{a}} \pm 2.35$ \\
\hline \multicolumn{5}{|l|}{ Phosphorous $(\mathrm{P})$} \\
\hline Recommended (g/day) & $21.02 \pm 0.07$ & $24.72 \pm 0.73$ & $17.68 \pm 0.28$ & $15.02 \pm 0.25$ \\
\hline Intake (g/day) & $27.96 \pm 0.59$ & $32.77 \pm 2.88$ & $21.65 \pm 0.47$ & $19.91 \pm 0.55$ \\
\hline Excess & $6.91 \pm 0.55$ & $8.05 \pm 2.51$ & $3.97 \pm 0.54$ & $4.89 \pm 0.52$ \\
\hline Excess $(\%)$ & $32.7^{\mathrm{ab}} \pm 2.64$ & $32.6^{\mathrm{b}} \pm 8.41$ & $22.5^{\mathrm{a}} \pm 3.26$ & $32.8^{\mathrm{a}} \pm 3.67$ \\
\hline Average milk yield (liters) & $8.5 \pm 0.03$ & $9.6 \pm 0.4$ & $5.1 \pm 0.4$ & -- \\
\hline
\end{tabular}

${ }^{\mathrm{ab}}$ Means in a row with different literal differ significantly $(\mathrm{P} \leq 0.05)$

Table-2: Percentage deficit /excess of nutrient intake of Hfx cows at different physiological stages in relation to NRC (2001) feeding standards

\begin{tabular}{|c|c|c|c|c|}
\hline Parameters & $\begin{array}{l}\text { Early lactation } \\
\qquad(\mathbf{n}=\mathbf{3 0})\end{array}$ & $\begin{array}{c}\text { Mid } \\
\text { lactation } \\
(\mathbf{n}=\mathbf{3 0}) \\
\end{array}$ & $\begin{array}{c}\text { Late } \\
\text { Lactation } \\
(n=23)\end{array}$ & $\begin{array}{l}\text { Late gestation } \\
\qquad(n=18)\end{array}$ \\
\hline Body weight ( kg) & $408 \pm 4^{b}$ & $437 \pm 12^{b}$ & $406^{b} \pm 8$ & $465^{a} \pm 7$ \\
\hline \multicolumn{5}{|l|}{ Dry matter (DM) } \\
\hline Requirement ( kg/day ) & $10.42 \pm 0.07$ & $13.19 \pm 0.28$ & $11.16 \pm 0.25$ & $9.69 \pm 0.10$ \\
\hline Intake (kg/day) & $9.28 \pm 0.15$ & $12.85 \pm 0.31$ & $9.92 \pm 0.26$ & $8.69 \pm 0.19$ \\
\hline Shortage $(\%)$ & $10.9^{\mathrm{a}} \pm 1.42$ & $2.5^{\mathrm{b}} \pm 1.27$ & $11.0^{\mathrm{a}} \pm 1.44$ & $10.3^{\mathrm{a}} \pm 2.09$ \\
\hline \multicolumn{5}{|c|}{ Total digestible nutrient (TDN) } \\
\hline Recommended (g/day ) & $6872.85 \pm 47.90$ & $8114.78 \pm 168.07$ & $6080.95 \pm 180.35$ & $5738.26 \pm 47.90$ \\
\hline Intake (g/day) & $6027.35 \pm 89.89$ & $7580.37 \pm 188.04$ & $5490.41 \pm 192.12$ & $5294.53 \pm 112.32$ \\
\hline Shortage (g/day) & $845.50 \pm 84.02$ & $534.41 \pm 64.44$ & $590.53 \pm 59.31$ & $443.73 \pm 108.28$ \\
\hline Intake (g/day) & $893.43 \pm 16.80$ & $1302.26 \pm 50.13$ & $772.31 \pm 36.57$ & $779.42 \pm 15.74$ \\
\hline Shortage (g/day) & $383.63 \pm 16.03$ & $319.71 \pm 33.96$ & $350.88 \pm 15.95$ & $217.92 \pm 16.08$ \\
\hline Shortage $(\%)$ & $30.0^{\mathrm{a}} \pm 1.18$ & $19^{\mathrm{b}} \pm 2.20$ & $31.4^{\mathrm{a}} \pm 1.53$ & $22.0^{\mathrm{b}} \pm 1.60$ \\
\hline
\end{tabular}


Assessment of Nutritional Status in Dairy Cows Using Biological Indicators

\begin{tabular}{|l|c|c|c|c|}
\hline Calcium (Ca) & & & & \\
\hline Recommended (g/day) & $58.95 \pm 0.77$ & $68.90 \pm 1.5$ & $48.32 \pm 1.42$ & $44.72 \pm 0.44$ \\
\hline Intake (g/day) & $45.12 \pm 1.52$ & $53.27 \pm 2.5$ & $43.34 \pm 3.35$ & $41.01 \pm 0.67$ \\
\hline Shortage (g/day) & $13.83 \pm 1.54$ & $15.63 \pm 3.02$ & $4.98 . \pm 0.31$ & $3.71 \pm 0.34$ \\
\hline Shortage (\%) & $23.4 \pm 2.60$ & $21.1^{\mathrm{a}} \pm 4.31$ & $10.2^{\mathrm{bc}} \pm 8.28$ & $8.2 \pm 1.56$ \\
\hline Phosphorous (P) & & & & \\
\hline Recommended (g/day) & $24.49 \pm 0.19$ & $31.13 \pm 0.66$ & $21.74 \pm 0.68$ & $16.80 \pm 0.12$ \\
\hline Intake (g/day) & $38.34 \pm 1.19$ & $32.62 \pm 2.17$ & $28.57 \pm 2.85$ & $26.84 \pm 1.55$ \\
\hline Excess & $13.85 \pm 1.14$ & $1.49 \pm 2.03$ & $6.83 \pm 2.29$ & $10.04 \pm 0.67$ \\
\hline Excess (\%) & $56.8^{\mathrm{a}} \pm 4.56$ & $4.7^{\mathrm{c}} \pm 7.74$ & $31.3 \pm 10.28$ & $59.8^{\mathrm{a}} \pm 5.32$ \\
\hline Average milk yield (liters) & $10.12 \pm 0.12$ & $12.11 \pm 0.4$ & $6.9 \pm 0.4$ & -- \\
\hline
\end{tabular}

${ }^{\mathrm{ab}}$ Means in a row with different literal differ significantly $(\mathrm{P} \leq 0.05)$

Table-3: Blood biochemical parameter of dairy cows at various physiological status .

\begin{tabular}{|c|c|c|c|c|}
\hline \multirow[t]{2}{*}{ Parameters } & \multicolumn{4}{|c|}{ Physiological stages } \\
\hline & Early Lactation & Mid Lactation & Late lactation & gestation \\
\hline \multicolumn{5}{|l|}{ Jersey crossbred } \\
\hline Glucose (mg/dl) & $46.75^{\mathrm{a}} \pm 1.16$ & $46.78^{\mathrm{a}} \pm 1.05$ & $42.73^{b} \pm 1.36$ & $46.68^{\mathrm{a}} \pm 0.86$ \\
\hline Cholesterol (mg/dl) & $189.00 \pm 15.00$ & $175.00 \pm 13.00$ & $142.00 \pm 13.00$ & $177.00 \pm 21.00$ \\
\hline NEFA (mmol/lit) & $0.61 \pm 0.05$ & $0.56 \pm 0.05$ & $0.57 \pm 0.06$ & $0.57 \pm 0.08$ \\
\hline Total protein $(\mathrm{g} / \mathrm{dl})$ & $8.80 \pm 0.19$ & $9.31 \pm 0.45$ & $8.94 \pm 0.19$ & $9.61 \pm 0.18$ \\
\hline Albumin $(\mathrm{g} / \mathrm{dl})$ & $3.15 \pm 0.09$ & $3.23 \pm 0.13$ & $3.26 \pm 0.12$ & $3.48 \pm 0.09$ \\
\hline Globulin (g/dl) & $5.64 \pm 0.22$ & $6.40 \pm 0.52$ & $5.77 \pm 0.22$ & $6.13 \pm 0.23$ \\
\hline BUN (mg/dl) & $15.56 \pm 0.46$ & $15.53 \pm 0.55$ & $15.47 \pm 0.49$ & $16.37 \pm 1.07$ \\
\hline MUN (mg/dl) & $8.81 \pm 0.07$ & $8.69 \pm 0.06$ & $8.75 \pm 0.04$ & - \\
\hline Calcium (mg/dl) & $7.29 \pm 0.30$ & $7.35 \pm 0.24$ & $7.26 \pm 0.20$ & $7.56 \pm 0.25$ \\
\hline Phosphorus (mg/dl) & $4.61^{\mathrm{b}} \pm 0.15$ & $4.73^{\mathrm{b}} \pm 0.18$ & $4.25^{\mathrm{b}} \pm 0.20$ & $5.71^{\mathrm{a}} \pm 0.26$ \\
\hline \multicolumn{5}{|c|}{ Holstein Friesian crossbred } \\
\hline Glucose $(\mathrm{mg} / \mathrm{dl})$ & $37.76^{\mathrm{d}} \pm 0.22$ & $47.76^{\mathrm{c}} \pm 0.34$ & $50.06^{\mathrm{b}} \pm 1.41$ & $52.17^{\mathrm{a}} \pm 0.19$ \\
\hline Cholesterol $(\mathrm{mg} / \mathrm{dl})$ & $108.00 \pm 6.42$ & $109.00 \pm 7.11$ & $104.00 \pm 7.00$ & $96.00 \pm 4.69$ \\
\hline NEFA (mmol/lit) & $0.60^{\mathrm{a}} \pm 0.04$ & $0.41^{\mathrm{b}} \pm 0.02$ & $0.72^{\mathrm{a}} \pm 0.11$ & $0.61^{\mathrm{a}} \pm 0.06$ \\
\hline Total protein $(\mathrm{g} / \mathrm{dl})$ & $8.31^{\mathrm{bc}} \pm 0.10$ & $8.50^{\mathrm{ab}} \pm 0.12$ & $7.88^{\mathrm{c}} \pm 0.19$ & $8.89^{\mathrm{a}} \pm 0.17$ \\
\hline Albumin (g/dl) & $3.17^{\mathrm{b}} \pm 0.07$ & $3.20^{\mathrm{b}} \pm 0.08$ & $3.04^{b} \pm 0.07$ & $3.73^{\mathrm{a}} \pm 0.18$ \\
\hline Globulin (g/dl) & $5.14 \pm 0.11$ & $5.31 \pm 0.14$ & $4.84 \pm 0.20$ & $5.15 \pm 0.25$ \\
\hline BUN (mg/dl) & $16.66^{\mathrm{b}} \pm 0.19$ & $18.13^{\mathrm{a}} \pm 0.28$ & $15.26^{\mathrm{c}} \pm 0.68$ & $15.38^{\mathrm{c}} \pm 0.40$ \\
\hline MUN (mg/dl) & $8.92^{b c} \pm 0.17$ & $9.58^{\mathrm{a}} \pm 0.10$ & $8.51^{\mathrm{c}} \pm 0.10$ & - \\
\hline Calcium (mg/dl) & $8.48^{b} \pm 0.07$ & $9.44^{\mathrm{a}} \pm 0.06$ & $8.71^{b} \pm 0.20$ & $8.49^{\mathrm{b}} \pm 0.18$ \\
\hline Phosphorus (mg/dl) & $6.54 \pm 0.27$ & $6.06 \pm 0.28$ & $5.74 \pm 0.28$ & $6.09 \pm 0.24$ \\
\hline
\end{tabular}

Table-4: Reference value of biological indicators for energy/protein status

\begin{tabular}{|c|c|c|c|c|c|c|c|c|c|c|c|}
\hline $\begin{array}{ll}\text { S.no } \\
\end{array}$ & $\begin{array}{l}\text { Glucose } \\
\text { (mg/dl) }\end{array}$ & $\begin{array}{l}\text { Cholesterol } \\
(\mathrm{mg} / \mathrm{dl})\end{array}$ & $\begin{array}{l}\text { NEFA } \\
(\mathrm{mmol} /)\end{array}$ & $\begin{array}{l}\text { Total protein } \\
\text { (g/dl) }\end{array}$ & $\begin{array}{c}\text { Albumin } \\
(\mathrm{g} / \mathrm{dl})\end{array}$ & $\begin{array}{l}\text { Globulin } \\
\text { (g/dl) }\end{array}$ & $\begin{array}{c}\mathrm{BUN} \\
(\mathrm{mg} / \mathrm{dl})\end{array}$ & $\begin{array}{l}\text { MUN } \\
(\mathrm{mg} / \mathrm{dl})\end{array}$ & $\mathrm{Ca}(\mathrm{mg} / \mathrm{dl})$ & $\mathrm{P}(\mathrm{mg} / \mathrm{dl})$ & Reference \\
\hline & & & & & & & & & & & Text books \\
\hline 1 & $35-55$ & $39-177$ & -- & $5.7-8.1$ & $2.1-3.6$ & $3.6-4.5$ & $6-27$ & - & $9.7-12.4$ & $5.6-6.5$ & Radostitis et al. (1994) \\
\hline 2 & $45-75$ & $55-88$ & 0.2 & $6.74-7.46$ & $3.03-3.55$ & $7.5-8.8$ & $20-30$ & - & - & - & $\begin{array}{l}\text { Jerry Kaneko et al. } \\
(1997)\end{array}$ \\
\hline 3 & $40-80$ & $75-150$ & - & - & - & - & $8.0-20$ & - & $8.0-10.5$ & $4.0-7.0$ & William O.Reece.(2005) \\
\hline 4 & $42-75$ & $62-193$ & - & $5.5-7.5$ & $2.6-4.0$ & $2.1-3.7$ & $8.8-26$ & - & $8.7-11.8$ & $2.9-6.2$ & $\begin{array}{l}\text { Merck Veterinary } \\
\text { Manual (2011) }\end{array}$ \\
\hline & & & & & & & & & & & Research publications \\
\hline 5 & $40-95$ & $53-417$ & $0.17-0.69$ & - & $1.6-5.5$ & - & $2.0-30.7$ & - & $6.5-12.3$ & $2.6-8.6$ & Kida,(2002) \\
\hline 6 & $55-57$ & $263-271$ & $0.20-0.32$ & $6.8-7$ & $3.3-3.4$ & $3.5-4.2$ & $4.9-7.1$ & & & & Hayashi et al.:(2005) \\
\hline 7 & $51-77$ & $43-331$ & $0.04-0.34$ & - & $3.2-4.1$ & - & $8-27$ & - & $8.2-10$ & $5.2-7.9$ & $\begin{array}{l}\text { Zinpro performance } \\
\text { panel(2011) }\end{array}$ \\
\hline 8 & - & - & - & - & - & - & $15.1-15.6$ & - & -- & - & Baker et al.(1995) \\
\hline 9 & - & - & - & - & - & - & $15-16$ & - & - & - & $\begin{array}{l}\text { Ferugson and Chalupa } \\
(1989)\end{array}$ \\
\hline 10 & - & -- & -- & - & - & - & $11-17$ & - & - & - & Hwang et al. $(2000)$ \\
\hline 11 & - & - & - & -- & - & - & $8.7-17.6$ & - & - & - & Wambugu et al. (1996) \\
\hline 12 & - & - & - & - & - & 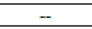 & - & - & $6.86-7.91$ & $3.42-4.43$ & Alacamet al.(2008) \\
\hline 13 & - & - & - & - & - & - & - & - & $8.7-11$ & $4.5-8.0$ & $\begin{array}{l}\text { Anderson and Rings } \\
(2009)\end{array}$ \\
\hline & & & & & & & & & & & Indian work \\
\hline 14 & 55.30 & 160.20 & - & 7.05 & 3.03 & 4.04 & 11.85 & - & 9.01 & 4.34 & Arunaman(2002) \\
\hline 15 & $\begin{array}{l}49.5- \\
59.0\end{array}$ & $97.7-126.4$ & - & $6.22-6.98$ & $3.14-3.89$ & $3.31-3.52$ & - & - & $9.11-10.27$ & $4.22-5.02$ & Ramakrishna (2003) \\
\hline 16 & - & - & - & - & - & $22-34$ & - & - & - & - & $\begin{array}{l}\text { Lazarus and Thiagarajan } \\
(1980)\end{array}$ \\
\hline 17 & - & - & - & - & - & - & $7-14$ & - & - & - & Somer (1991) \\
\hline 18 & - & - & - & - & - & - & $11-16$ & - & - & - & Wa dhaawa et al.(2005) \\
\hline 19 & - & - & - & - & - & - & $4.67-9.45$ & - & - & - & $\begin{array}{l}\text { Bakshi andWadhwa } \\
\text { (2011) }\end{array}$ \\
\hline
\end{tabular}

